\title{
HUBUNGAN KADAR GLIAL FIBRILLARY ACIDIC PROTEIN (GFAP) SERUM DENGAN LUARAN KLINIS NEUROLOGIS PASIEN STROKE HEMORAGIK
}

\author{
THE CORRELATION BETWEEN SERUM LEVELS OF GLIAL FIBRILLARY ACIDIC PROTEIN \\ (GFAP) WITH NEUROLOGICAL CLINICAL OUTCOME OF \\ HEMORRHAGIC STROKE PATIENT
}

Theodorus Kevin Hendartono, * Retnaningsih, * Amin Husni*

\section{ABSTRACT}

Introduction: Glial fibrillary acidic protein (GFAP) is a protein that is responsible for the cytoskeleton structure of glial cells. Increased level of GFAP can be used to predict the level of glial cells damage that accompanies a hemorrhagic stroke. National Institute of Health Stroke Scale (NIHSS) and modified Rankin Scale (mRS) are the measurement scales that have high validity and reliability for determining the long-term functional clinical output of hemorrhagic stroke patients.

Aims: To determine the correlation between serum levels of GFAP with neurological clinical outcome of hemorrhagic stroke patients.

Methods: Prospective cohort study were conducted at Dr. Kariadi Hospital Semarang in the period of JulyNovember 2018. Serum blood sampling for GFAP examination was carried out in less than 72 hours from the stroke onset. Then the third and seventh day NIHSS and 30-day mRS were assessed. Statistical analyses were performed to assess the correlation between serum levels of GFAP with neurological clinical outcome of hemorrhagic stroke patients.

Results: The study found 33 subjects of hemorrhagic stroke patients. Multivariate analysis showed that the serum GFAP levels were significant for NIHSS changes ( $p=0.003$; OR=1.397). Significant differences were also obtained at serum GFAP levels with 30-day $m R S$ ( $p=0.009 ;$ OR=1.603).

Discussion: Serum GFAP levels taken in less than 72 hours from the hemorrhagic stroke onset are associated with neurological clinical outcome of hemorrhagic stroke patients. Stroke Scale

Keywords: Glial fibrillary acidic protein, hemorrhagic stroke, modified Rankin Scale, National Institute of Health

\section{ABSTRAK}

Pendahuluan: Glial fibrillary acidic protein (GFAP) merupakan protein yang bertanggung jawab terhadap struktur sitoskeleton dari sel glia. Peningkatan kadar GFAP dapat digunakan untuk memprediksi tingkat kerusakan sel glia yang menyertai stroke hemoragik. National Institute of Health Stroke Scale (NIHSS) dan modified Rankin Scale (mRS) merupakan skala pengukuran yang memiliki validitas dan reliabilitas yang tinggi untuk penentuan luaran klinis fungsional jangka panjang pasien stroke hemoragik.

Tujuan: Mengetahui hubungan kadar GFAP serum dengan luaran klinis neurologis pasien stroke hemoragik.

Metode: Penelitian kohort prospektif yang dilakukan di RSUP Dr. Kariadi Semarang selama bulan Juli-November 2018. Pengambilan sampel darah serum untuk pemeriksaan GFAP dilakukan dalam $\leq 72$ jam pertama onset stroke. Kemudian dinilai skor NIHSS hari ketiga, NIHSS hari ketujuh dan mRS hari ke-30. Data diolah dan dilakukan analisis statistik untuk menilai hubungan kadar GFAP serum dengan luaran klinis neurologis pasien stroke hemoragik.

Hasil: Pada penelitian didapatkan 33 subjek pasien stroke hemoragik. Analisis multivariat didapatkan kadar GFAP serum bermakna secara signifikan terhadap perubahan NIHSS ( $\mathrm{p}=0,003 ; \mathrm{RO}=1,397)$. Perbedaan yang bermakna secara signifikan juga diperoleh pada kadar GFAP serum dengan mRS 30 hari $(\mathrm{p}=0,009 ; \mathrm{RO}=1,603)$.

Diskusi: Kadar GFAP serum yang diambil $\leq 72$ jam pertama onset stroke hemoragik berhubungan dengan luaran klinis neurologis pasien stroke hemoragik. hemoragik

Kata kunci: Glial fibrillary acidic protein, modified Rankin Scale, National Institute of Health Stroke Scale, stroke *Bagian/SMF Neurologi FK Universitas Diponegoro/RSUP Dr. Kariadi, Semarang. Korespondensi: theodorus.kevin88@gmail.com.

\section{PENDAHULUAN}

Perdarahan intraserebral (PIS) didefinisikan sebagai perdarahan fokal di dalam parenkim otak tanpa adanya riwayat trauma sebelumnya. Perdarahan intraserebral menyumbang sekitar 20\% dari seluruh kejadian stroke di Asia. ${ }^{1-2}$ Angka insiden kejadian berkisar 24,6 per 100.000 penduduk dan semakin meningkat seiring bertambahnya usia seseorang. ${ }^{3}$ 
Angka kematian pada PIS dalam 1 bulan pertama sekitar 40\%, dengan 50\% dari seluruh kematian terjadi dalam 2 hari pertama. Sebanyak $69 \%$ dari seluruh pasien yang berhasil bertahan hidup mengalami kecacatan dan bergantung pada orang lain secara fungsional dalam 3 bulan setelah PIS., ${ }^{4-6}$

Hingga saat ini pencitraan otak tetap menjadi baku emas untuk penegakan diagnosis stroke hemoragik (SH). Namun demikian, ada keterbatasan, terutama dalam jam-jam pertama setelah onset stroke. Computerized Tomography (CT) scan secara akurat dapat mengidentifikasi kasus PIS, namun relatif kurang sensitif dalam mendeteksi perdarahan akut dan kecil. ${ }^{7}$ Oleh karena itu dipikirkan strategi diagnostik lain untuk membantu penegakan diagnostik SH yaitu dengan pemeriksaan penanda. ${ }^{8}$ Penanda memiliki potensi untuk evaluasi tingkat keparahan cedera otak pada SH dan dapat memprediksi luaran yang buruk sebagai bagian dari penentuan prognosis pasien stroke. Biomarker yang telah diteliti pada SH adalah glial fibrillary acidic protein (GFAP). ${ }^{8-9}$

Glial fibrillary acidic protein merupakan protein intermediate filament III (IF III) yang sangat spesifik untuk jaringan otak serta bertanggung jawab untuk mempertahankan struktur dan migrasi sel astroglia. Pada kondisi fisiologis, GFAP tidak secara aktif disekresi oleh sel, dan secara umum tidak terdeteksi dalam darah individu yang sehat. ${ }^{9-13}$ Berbagai studi menunjukkan bahwa GFAP akan dilepaskan secara cepat pada kasus SH akut, dimana kadarnya akan mencapai puncak dalam 12 jam onset dan dipertahankan hingga 72 jam onset. ${ }^{8,14-15}$

\section{National Institutes of Health Stroke Scale} (NIHSS) merupakan suatu skala pengukuran derajat beratnya stroke. National Institutes of Health Stroke Scale menjadi indikator pemeriksaan untuk mengukur defisit neurologis pasien stroke secara kuantitatif. Perubahan NIHSS yang dinilai berdasarkan selisih skor NIHSS awal dengan skor NIHSS hari ketujuh memiliki validitas tinggi dalam memprediksi luaran klinis jangka panjang. ${ }^{16}$

Modified Rankin Scale (mRS) merupakan skala pengukuran yang terdiri dari 7 skala, mulai dari 0 yaitu tidak ada disabilitas, hingga 6 yaitu meninggal.
Modified Rankin Scale telah dipakai secara luas dalam penentuan gangguan fungsional dan derajat disabilitas. Skala pengukuran mRS 30 hari onset SH memiliki validitas dan reliabilitas tinggi, mudah dilakukan, serta dapat menjadi prediktor luaran fungsional jangka panjang. ${ }^{17-18}$

Berdasarkan uraian di atas menjadi dasar dilakukannya penelitian mengenai hubungan kadar GFAP serum dengan luaran klinis neurologis pasien SH yang diwakili oleh perubahan NIHSS dan mRS 30 hari.

\section{METODE}

Penelitian ini merupakan penelitian observasional analitik dengan pendekatan kohort prospektif. Subjek adalah pasien yang didiagnosis SH di instalasi rawat inap SMF Neurologi RSUP Dr. Kariadi Semarang mulai bulan Juli hingga November 2018 dan memenuhi kriteria inklusi sebagai berikut: 1) Pasien stroke hemoragik (perdarahan intraserebral) yang telah dibuktikan dengan pemeriksaan CT scan kepala polos; 2) Menderita SH pertama kali; 3) Onset $\leq 72$ jam; 4) Setuju ikut penelitian (informed consent); dan tidak memiliki kriteria eksklusi sebagai berikut: 1) Pasien SH yang telah menjalani tindakan operatif sebelumnya; 2) Riwayat penyakit autoimun; 3) Riwayat cedera otak traumatik dalam 3 bulan terakhir; 4) Riwayat tumor otak; 5) Riwayat terdiagnosis demensia Alzheimer; 6) Riwayat infeksi sebelum onset $\mathrm{SH}$ (demam $>38^{\circ} \mathrm{C}$, batuk berdahak, sesak); 7) Pasien dengan ICH score $>3$.

Adapun kriteria eksklusi adalah: 1) Pasien yang tidak diketahui perkembangannya/tidak dapat dikontak, baik pasien maupun keluarganya, dalam follow up sesuai waktu yang ditentukan; 2) Pasien yang mengalami kejadian stroke berulang dalam masa follow up; 3) Pasien meninggal sebelum tujuh hari perawatan di rumah sakit. Penelitian ini telah memperoleh Surat Keterangan Etik dari Komite Etik Penelitian Kesehatan (KEPK) Fakultas Kedokteran Universitas Diponegoro, Semarang.

Pencarian responden penelitian dilakukan di unit gawat darurat (UGD). Pada saat pasien datang pertama kali, dilakukan informed consent, anamnesis, pemeriksaan fisik neurologis, pemeriksaan CT scan 
kepala, pengisian kuesioner penelitian, penghitungan skor NIHSS, pengambilan sampel darah vena sebanyak $4 \mathrm{~mL}$ di UGD/rawat inap SMF Neurologi RSUP Dr. Kariadi Semarang. Sampel darah dibawa ke laboratorium sentral RSUP Dr. Kariadi Semarang.

Penilaian kadar GFAP serum diambil $\leq 72$ jam pertama onset. Sampel darah dibiarkan membeku dan disentrifugasi untuk memisahkan serum. Penyimpanan pada suhu $-80^{\circ} \mathrm{C}$ hingga seluruh sampel penelitian terkumpul. Seluruh sampel kemudian dibawa ke laboratorium GAKI FK Undip, Semarang. Kadar GFAP serum dinilai dengan metode ELISA (Enzyme-linked Imunosorbent Assay) menggunakan Human GFAP ELISA Kit dari Elabscience (Catalog No: E-EL-H1888, China).

Pada follow up hari ketujuh diperiksa kembali skor NIHSS. Pada hari ke-30 setelah onset SH dilakukan penilaian luaran klinis fungsional berdasarkan mRS saat pasien kontrol ke rumah sakit atau dengan melakukan kunjungan rumah. Kelompok perbaikan NIHSS apabila didapatkan selisih skor NIHSS antara hari ketiga dan ketujuh $\geq 4$, sedangkan kelompok tidak ada perbaikan NIHSS apabila didapatkan selisih skor NIHSS antara hari ketiga dan ketujuh $<4$. Kelompok luaran klinis fungsional baik apabila didapatkan mRS 30 hari sebesar 0-2, sedangkan kelompok luaran klinis fungsional jelek apabila didapatkan mRS 30 hari sebesar 3-6.

Seluruh data kemudian dikumpulkan, ditabulasi, dan dianalisis secara statistik dengan program "SPSS for Windows versi 22". Analisis data dilakukan dalam tiga tahapan. Tahap pertama adalah tahapan statistik deskriptif untuk menentukan karakteristik dasar subjek penelitian. Tahap kedua adalah tahapan analisis bivariat untuk menentukan korelasi antar variabel. Kadar GFAP serum berskala numerik dilakukan uji normalitas Shapiro-Wilk. Uji komparatif antara kadar GFAP serum dan perubahan NIHSS (skala nominal) serta mRS 30 hari (skala nominal) dilakukan uji independent t-test karena sebaran datanya normal. Selanjutnya dilakukan analisis multivariat variabel yang paling bermakna yang dapat memengaruhi luaran klinis penderita dengan menggunakan metode regresi logistik.

\section{HASIL}

Pada akhir penelitian diperoleh 33 subjek yang valid untuk dianalisis. Karakteristik demografi pasien dapat dilihat pada tabel 1. Rerata volume PIS pada subjek penelitian ini adalah $15,69 \pm 9,2 \mathrm{~mL}$ dengan rentang 5,16-37,39 (median=12,68)mL. Ada 16 subjek penelitian (48,5\%) dengan disertai perdarahan intraventrikel pada gambaran CT scan kepala polos. Sebagian besar subjek penelitian kami mendapatkan prosedur tata laksana konservatif yaitu sebesar 31 orang $(93,9 \%)$, sementara 2 orang $(6,1 \%)$ menjalani tindakan operatif berupa Extraventricular Drainage (EVD). Rerata lama perawatan adalah $11,64 \pm 5,09$ hari dengan rentang perawatan 7-25 (median=10) hari. Rerata skor NIHSS hari ketiga dan hari ketujuh dapat dilihat pada tabel 1 . Subjek penelitian kemudian dibandingkan skor NIHSS hari ketiga dan hari ketujuh untuk penentuan perubahan NIHSS. Pada 15 subjek $(45,5 \%)$ terjadi penurunan skor NIHSS $\geq 4$ (perbaikan NIHSS), sementara 18 subjek (54,5\%) terjadi penurunan skor NIHSS $<4$ atau peningkatan skor NIHSS (tidak ada perbaikan NIHSS). Setelah diikuti selama 30 hari/sesudah 7 hari perawatan di RS, sebanyak 14 subjek $(42,4 \%)$ didapatkan luaran klinis yang baik (mRS 0-2) sementara 19 subjek $(57,6 \%)$ didapatkan luaran klinis yang jelek (mRS 3-6). Kadar GFAP serum yang diukur memiliki rerata $14,19 \pm 7,69 \mathrm{ng} / \mathrm{mL}$ dengan rentang $4,1-30,5$ (median=15)ng/mL (Tabel 1).

Kadar GFAP serum pada subjek penelitian yang mengalami perbaikan NIHSS lebih rendah secara bermakna dibandingkan kadar GFAP serum pada subjek penelitian yang tidak ada perbaikan NIHSS ( $<<0,001$; Tabel 2). Berdasarkan hasil diatas, maka hipotesis yang menyatakan bahwa terdapat hubungan kadar GFAP serum dengan perubahan NIHSS terbukti.

Kadar GFAP serum pada subjek luaran klinis baik lebih rendah bermakna dibandingkan subjek luaran klinis jelek yang dinilai berdasarkan mRS $(\mathrm{p}<0,001$; Tabel 2). Berdasarkan hasil diatas, maka hipotesis yang menyatakan bahwa terdapat hubungan kadar GFAP serum dengan mRS 30 hari terbukti. 
Tabel 1. Data Karakteristik Subjek Penelitian $(n=33)$

\begin{tabular}{|c|c|c|c|}
\hline Variabel & Jumlah (\%) & Rerata \pm SD & Median (Min-Maks) \\
\hline \multicolumn{4}{|l|}{ Jenis Kelamin } \\
\hline - Laki-laki & $22(66,7)$ & & \\
\hline - Perempuan & $11(33,3)$ & & \\
\hline Umur & & $56,85 \pm 11,8$ & $57(25-79)$ \\
\hline - $<65$ tahun & $23(69,7)$ & & \\
\hline - $\geq 65$ tahun & $10(30,3)$ & & \\
\hline IMT & & $22,9 \pm 3,5$ & $22,58(15,6-31,24)$ \\
\hline - Underweight & $4(12,1)$ & & \\
\hline - Normoweight & $15(45,5)$ & & \\
\hline - Overweight & $8(24,2)$ & & \\
\hline - Obesitas & $6(18,2)$ & & \\
\hline Onset (Jam) & & $23,98 \pm 23$ & $24(1-72)$ \\
\hline GCS & & & $14(6-15)$ \\
\hline - $13-15$ & $22(66,7)$ & & \\
\hline - $5-12$ & $11(33,3)$ & & \\
\hline \multicolumn{4}{|l|}{ Hipertensi } \\
\hline - Ya & $26(78,8)$ & & \\
\hline - Tidak & $7(21,2)$ & & \\
\hline \multicolumn{4}{|l|}{ DM } \\
\hline - Ya & $5(15,2)$ & & \\
\hline - Tidak & $28(84,8)$ & & \\
\hline \multicolumn{4}{|l|}{ Dislipidemia } \\
\hline - Ya & $16(48,5)$ & & \\
\hline - Tidak & $17(51,5)$ & & \\
\hline \multicolumn{4}{|l|}{ Lokasi PIS } \\
\hline - Supratentorial & $29(87,9)$ & & \\
\hline - Infratentorial & $4(12,1)$ & & \\
\hline Volume PIS & & $15,69 \pm 9,2$ & $12,68(5,16-37,39)$ \\
\hline - $<30 \mathrm{cc}$ & $29(87,9)$ & & \\
\hline - $\geq 30 \mathrm{cc}$ & $4(12,1)$ & & \\
\hline \multicolumn{4}{|l|}{ IVH } \\
\hline - Ada & $16(48,5)$ & & \\
\hline - Tidak ada & $17(51,5)$ & & \\
\hline Hari Perawatan & & $11,64 \pm 5,1$ & $10(7-25)$ \\
\hline NIHSS H-3 & & $13,06 \pm 4,4$ & $12(8-25)$ \\
\hline NIHSS H-7 & & $11,61 \pm 8,1$ & $9(4-31)$ \\
\hline \multicolumn{4}{|l|}{ Perubahan NIHSS } \\
\hline - Perbaikan & $15(45,5)$ & & \\
\hline - Tidak perbaikan & $18(54,5)$ & & \\
\hline \multicolumn{4}{|l|}{ mRS 30 Hari } \\
\hline - Luaran baik & $14(42,4)$ & & \\
\hline - Luaran buruk & $19(57,6)$ & & \\
\hline $\operatorname{GFAP}(n g / m L)$ & & $14,19 \pm 7,7$ & $15(4,1-30,5)$ \\
\hline
\end{tabular}

IMT: indeks massa tubuh; GCS: Glasgow Coma Scale; DM: diabetes melitus; PIS: perdarahan intraserebral; IVH: intraventricular hemorrhage; NIHSS: National Institute of Health Stroke Scale; mRS: modified Rankin Scale; GFAP: glial fibrillary acidic protein. 
Tabel 2. Uji Hubungan antara Kadar GFAP Serum dengan Perubahan NIHSS dan mRS 30 hari (n=33)

\begin{tabular}{|c|c|c|c|c|c|c|}
\hline \multirow[b]{2}{*}{ Variabel } & \multicolumn{2}{|c|}{ Perbaikan NIHSS } & \multirow[b]{2}{*}{$\mathbf{p}$} & \multicolumn{2}{|c|}{ mRS 30 hari } & \multirow[b]{2}{*}{$\mathbf{p}$} \\
\hline & Ya $(n=15)$ & Tidak $(n=18)$ & & $\begin{array}{l}\text { Luaran Baik } \\
\quad(n=14)\end{array}$ & $\begin{array}{c}\text { Luaran Buruk } \\
(\mathrm{n}=19)\end{array}$ & \\
\hline Kadar GFAP Serum & $8,77 \pm 5,9$ & $18,71 \pm 5,9$ & $<0,001$ & $8,36 \pm 4,30$ & $18,48 \pm 6,77$ & $<0,001$ \\
\hline \multicolumn{7}{|c|}{$\begin{array}{l}\text { *Uji independent T-test; GFAP: glial fibrillary acidic protein; NIHSS: National Institute of Health Stroke Scale; mRS: modified } \\
\text { Rankin Scale. }\end{array}$} \\
\hline \multicolumn{7}{|c|}{ Tabel 3. Uji Bivariat Hubungan Faktor Perancu dengan Perubahan NIHSS dan mRS 30 Hari } \\
\hline \multirow[b]{2}{*}{ Variabel } & \multicolumn{2}{|c|}{ Perubahan NIHSS } & \multirow[b]{2}{*}{ p } & \multicolumn{2}{|c|}{ mRS 30hr } & \multirow[b]{2}{*}{$\mathbf{p}$} \\
\hline & Perbaikan & $\begin{array}{l}\text { Tidak Ada } \\
\text { Perbaikan }\end{array}$ & & Luaran Baik & Luaran Buruk & \\
\hline \multicolumn{7}{|l|}{ Jenis Kelamin } \\
\hline - Laki-laki & $9(60 \%)$ & $3(72,2 \%)$ & $0,458^{¥}$ & $7(50 \%)$ & $15(78,9 \%)$ & $0,136^{£}$ \\
\hline - Perempuan & $6(40 \%)$ & $5(27,8 \%)$ & & $7(50 \%)$ & $4(21,1 \%)$ & \\
\hline \multicolumn{7}{|l|}{ Umur } \\
\hline - $<65$ th & $11(73,3 \%)$ & $12(66,7 \%)$ & $0,722^{£}$ & $11(78,6 \%)$ & $12(63,2 \%)$ & $0,455^{\mathfrak{1}}$ \\
\hline - $\geq 65$ th & $4(26,7 \%)$ & $6(33,3 \%)$ & & $3(21,4 \%)$ & $7(36,8 \%)$ & \\
\hline \multicolumn{7}{|l|}{ IMT } \\
\hline - Underweight & $1(6,7 \%)$ & $3(16,7 \%)$ & 0,899 & $1(7,1 \%)$ & $3(15,8 \%)$ & 0,999 \\
\hline - Normoweight & $6(40 \%)$ & $9(50 \%)$ & & $6(42,9 \%)$ & $9(47,4 \%)$ & \\
\hline - Overweight & $5(33,3 \%)$ & $3(16,7 \%)$ & & $4(28,6 \%)$ & $4(21,1 \%)$ & \\
\hline - Obesitas & $3(20 \%)$ & $3(16,7 \%)$ & & $3(21,4 \%)$ & $3(15,8 \%)$ & \\
\hline \multicolumn{7}{|l|}{ Hipertensi } \\
\hline - Ya & $10(66,7 \%)$ & $16(88,9 \%)$ & $0,203^{£}$ & $12(85,7 \%)$ & $14(73,7 \%)$ & $0,670^{£}$ \\
\hline - Tidak & $5(33,3 \%)$ & $2(11,1 \%)$ & & $2(14,3 \%)$ & $5(26,3 \%)$ & \\
\hline \multicolumn{7}{|l|}{ DM } \\
\hline - Ya & 0 & $5(27,8 \%)$ & $0,328^{£}$ & $0(0 \%)$ & $5(26,3 \%)$ & $0,263^{£}$ \\
\hline - Tidak & $15(100 \%)$ & $13(72,2 \%)$ & & $14(100 \%)$ & $14(73,7 \%)$ & \\
\hline $\begin{array}{l}\text { GCS } \\
-13-15 \\
\text { - } 5-12\end{array}$ & $\begin{array}{l}12(80 \%) \\
3(20 \%)\end{array}$ & $\begin{array}{l}10(55,6 \%) \\
8(44,4 \%)\end{array}$ & $0,138^{¥}$ & $\begin{array}{l}12(85,7 \%) \\
2(14,3 \%)\end{array}$ & $\begin{array}{l}10(52,6 \%) \\
9(47,4 \%)\end{array}$ & $0,067^{£}$ \\
\hline $\begin{array}{l}\text { Lokasi PIS } \\
\text { - Supratentorial } \\
\text { - Infratentorial }\end{array}$ & $\begin{array}{c}13(86,7 \%) \\
2(13,3 \%)\end{array}$ & $\begin{array}{c}16(88,9 \%) \\
2(11,1 \%)\end{array}$ & $1,000^{\mathfrak{f}}$ & $\begin{array}{c}11(78,6 \%) \\
3(21,4 \%)\end{array}$ & $\begin{array}{c}18(94,7 \%) \\
1(5,3 \%)\end{array}$ & $0,288^{£}$ \\
\hline $\begin{array}{l}\text { Volume PIS } \\
\text { - }<30 \mathrm{~mL} \\
\cdot \geq 30 \mathrm{~mL}\end{array}$ & $\begin{array}{c}14(93,3 \%) \\
1(6,7 \%)\end{array}$ & $\begin{array}{c}15(83,3 \%) \\
3(16,7 \%)\end{array}$ & $0,607^{\mathfrak{f}}$ & $\begin{array}{c}14(100 \%) \\
0\end{array}$ & $\begin{array}{c}15(78,9 \%) \\
4(21,1 \%)\end{array}$ & $0,319^{£}$ \\
\hline $\begin{array}{l}\text { IVH } \\
\text { - Ada } \\
\text { - Tidak ada }\end{array}$ & $\begin{array}{l}8(53,3 \%) \\
7(46,7 \%)\end{array}$ & $\begin{array}{c}8(44,4 \%) \\
10(55,6 \%)\end{array}$ & $0,611^{¥}$ & $\begin{array}{l}7(50 \%) \\
7(50 \%)\end{array}$ & $\begin{array}{c}9(47,4 \%) \\
10(52,6 \%)\end{array}$ & $0,881^{¥}$ \\
\hline
\end{tabular}

${ }^{¥}$ Pearson Chi-square; ${ }^{£}$ Fisher's exact; "Kolmogorov-Smirnov 2 sampel; NIHSS: National Institute of Health Stroke Scale; mRS: modified Rankin Scale; IMT: indeks massa tubuh; DM: diabetes melitus; GCS: Glasgow Coma Scale; PIS: perdarahan intraserebral; IVH: intraventricular hemorrhage.

Setelah dilakukan uji bivariat antara variabelvariabel terhadap perubahan NIHSS (Tabel 3), selanjutnya dilakukan uji analisis multivariat. Variabel yang dimasukkan dalam analisis multivariat adalah GCS, hipertensi, dan kadar GFAP serum. Hasil analisis regresi logistik antara variabel-variabel dengan perubahan NIHSS menunjukkan bahwa variabel yang paling berpengaruh terhadap perubahan 
NIHSS pasien stroke hemoragik adalah kadar GFAP serum $(\mathrm{p}=0,003 ; \mathrm{RO}=1,397)$ (Tabel 4).

Tabel 4. Analisis Regresi Logistik Variabel-variabel dengan Perubahan NIHSS

\begin{tabular}{lccc}
\hline \multicolumn{1}{c}{ Variabel } & $\mathbf{p}$ & RO & IK 95\% (Min-Maks) \\
\hline GCS & 0,488 & 2,865 & $0,147-55,905$ \\
Hipertensi & 0,178 & 0,124 & $0,006-2,578$ \\
GFAP Serum & $0,002 *$ & 1,350 & $1,112-1,640$ \\
\hline
\end{tabular}

RO: rasio Odds; IK: interval kepercayaan; GCS: Glasgow Coma Scale; GFAP: glial fibrillary acidic protein.

Berdasarkan hasil uji analisis bivariat variabelvariabel terhadap mRS 30 hari, variabel jenis kelamin, GCS, dan kadar GFAP serum memenuhi syarat untuk dilakukan analisis multivariat. Hasil analisis regresi logistik antara variabel-variabel dengan mRS 30 hari menunjukkan bahwa variabel yang paling berpengaruh terhadap mRS 30 hari adalah kadar GFAP serum ( $\mathrm{p}=0,009 ; \mathrm{RO}=1,603)$. Variabel jenis kelamin juga berpengaruh terhadap mRS 30 hari ( $\mathrm{p}=0,036$; $\mathrm{RO}=0,013)$ (Tabel 5).

Tabel 5. Analisis Regresi Logistik Variabel-variabel dengan mRS 30 Hari

\begin{tabular}{lccc}
\hline \multicolumn{1}{c}{ Variabel } & $\mathbf{p}$ & RO & IK 95\% \\
\hline Jenis kelamin & $0,036^{*}$ & 0,013 & $0,0000-0,751$ \\
GCS & 0,435 & 0,583 & $0,150-2,262$ \\
GFAP serum & $0,009 *$ & 1,603 & $1,127-2,231$ \\
\hline
\end{tabular}

RO: rasio Odds; IK: interval kepercayaan; GCS: Glasgow Coma Scale; GFAP: glial fibrillary acidic protein.

\section{PEMBAHASAN}

Sebagian besar subjek adalah laki-laki dan hal ini sesuai dengan data penelitian epidemiologi subjek SH, dimana jenis kelamin laki-laki lebih banyak dibandingkan perempuan. ${ }^{1-2}$ Studi dari Xing dkk di China dengan subjek 1.325 pasien, didapatkan 897 laki-laki $(67,7 \%)$ dan 428 perempuan (32,3\%). Studi ini menyatakan bahwa laki-laki memiliki risiko mortalitas yang lebih tinggi dalam 3 bulan pascaSH dibanding perempuan. ${ }^{19}$ Studi populasi berskala besar dilakukan di Eropa dan dipublikasikan tahun 2018 dengan subjek 13.775 perempuan dan 13.916 laki-laki. Setelah dilakukan penyesuaian analisis multivariat antar variabel, subjek berjenis kelamin perempuan memiliki angka harapan hidup dalam 1 tahun pasca-SH yang lebih tinggi $(\mathrm{p}<0,001$; $\mathrm{RO}=1,17$ ) dibandingkan subjek berjenis kelamin laki-laki. Hal ini terkait usia saat onset stroke, tingkat keparahan gejala klinis, serta faktor sosioekonomi. ${ }^{20}$

Rerata umur subjek penelitian ini adalah 56,85 tahun dengan rentang umur antara 25-79 tahun. Subjek berjenis kelamin laki-laki memiliki rerata umur 56,82 tahun sedangkan subjek perempuan memiliki rerata umur 59,91 tahun. Hasil penelitian sesuai dengan literatur maupun penelitian-penelitian yang telah dilakukan dimana subjek perempuan cenderung menderita $\mathrm{SH}$ pada rerata umur yang lebih tinggi dibandingkan subjek laki-laki. Kejadian SH pada laki-laki cenderung terjadi pada rerata umur yang lebih muda. Namun pada kelompok umur 80 tahun atau lebih didapatkan angka kejadian $\mathrm{SH}$ cenderung lebih tinggi pada perempuan dibandingkan laki-laki. ${ }^{2,20-21}$ Umur menjadi salah satu indikator prognostik yang tidak dapat diubah pada stroke hemoragik. Studi oleh Camacho dkk didapatkan bahwa cut off umur yang berpengaruh terhadap morbiditas dan mortalitas pasien SH adalah 65 tahun. Hal ini dapat dijelaskan bahwa subjek dengan usia lanjut memiliki cedera sistem saraf yang cenderung lebih parah tanpa mempedulikan volume atau luas PIS, kemudian kemungkinan lain bahwa pada pasien usia lanjut membuat keputusan perawatan medis menjadi kurang agresif karena banyak faktor yang memengaruhi. ${ }^{22}$

Hasil penelitian kami menunjukkan tidak didapatkannya hubungan yang bermakna antara IMT dengan luaran klinis neurologis pasien SH. Hal ini dapat disebabkan sampel penelitian yang terlalu kecil, lebih banyak subjek penelitian kami dengan IMT normoweight yaitu mencapai $45,5 \%$ dari seluruh subjek. Subjek dengan IMT overweight berjumlah 8 subjek (24,2\%) dan IMT obesitas berjumlah 6 subjek $(18,2 \%)$.

Peningkatan tekanan darah merupakan kondisi yang sangat umum pada SH akut. Hal ini disebabkan oleh berbagai faktor, termasuk stres fisik, nyeri, peningkatan tekanan intrakranial, dan kondisi premorbid akut atau peningkatan persisten dari tekanan darah. Tingginya tekanan darah sistolik berkaitan dengan perluasan hematoma, peningkatan defisit neurologis, kematian dan dependensi pascakejadian SH. $^{4,23}$ Sebanyak $78,8 \%$ subjek 
penelitian ini mengalami hipertensi saat onset $\mathrm{SH}$, dimana hipertensi berdampak tidak adanya perbaikan NIHSS serta luaran klinis jelek dengan subjek yang lebih besar. Namun setelah dilakukan analisis statistik, tidak didapatkan hubungan yang bermakna antara hipertensi dengan luaran klinis neurologis pasien $\mathrm{SH}$. Tekanan darah pada penelitian kami hanya diukur satu kali pada saat awal onset. Variasi tekanan darah dapat berpengaruh terhadap luaran klinis. Studi oleh Lattanzi dkk menyatakan bahwa penurunan tekanan darah secara intensif dalam 24 jam pertama onset $\mathrm{SH}$ efektif dalam memperbaiki luaran klinis pasien. ${ }^{24}$

Pada penelitian ini didapatkan kadar GFAP serum memiliki hubungan yang bermakna dengan luaran klinis neurologis pasien stroke hemoragik. Setelah dilakukan analisis multivariat didapatkan hasil kadar GFAP serum memiliki hubungan yang bermakna dengan perubahan NIHSS $(\mathrm{p}=0,003$; $\mathrm{RO}=1,397)$, serta $\mathrm{mRS} 30$ hari $(\mathrm{p}=0,009 ; \mathrm{RO}=1,603)$.

Glial fibrillary acidic protein merupakan suatu intermediate filament utama penyokong sitoskeleton astrosit. Sebagai bagian protein astroglial, GFAP memainkan peranan penting dalam menjaga bentuk dan motilitas dari proses astrositik. Glial fibrillary acidic protein juga berkontribusi terhadap arsitektur substansia alba, proses mielinasi dan mempertahankan integritas sawar darah otak. Dari beberapa literatur, GFAP dikatakan memiliki spesifisitas pada otak yang tinggi, oleh karena sumber yang relevan dari ekstraserebral untuk protein ini belum teridentifikasi. Sebagai suatu protein struktural, GFAP tidak dilepaskan dari sel astroglia dalam kondisi fisiologis normal, dan tidak ada kadar GFAP yang terdeteksi dalam serum darah individu yang sehat. ${ }^{9-13}$ Makna penting dari pelepasan GFAP dari jaringan otak ke dalam aliran darah adalah penanda hilangnya integritas struktural astrositik akibat nekrosis sel dan atau disrupsi mekanis serta terjadinya disintegrasi struktur sawar darah otak. . $^{1525-26}$

Beberapa studi menyatakan bahwa GFAP dapat menjadi biomarker darah yang potensial pada kasus SH. Glial fibrillary acidic protein akan dilepaskan secara cepat dalam kasus perdarahan parenkim yang meluas di otak dan dengan segera menyebabkan kerusakan sel sementara pada kasus stroke iskemik kadar GFAP akan lambat terdeteksi dikarenakan proses nekrosis dan disintegrasi seluler tidak terjadi hingga 12 jam onset gejala. ${ }^{10,26}$ Kadar GFAP pada kasus PIS akan mencapai puncak dalam 12 jam onset dan dipertahankan hingga 72 jam onset sebelum berangsur-angsur menghilang dalam 7-10 hari. ${ }^{15}$

Telah banyak studi yang meneliti kadar GFAP serum sebagai alat diagnostik PIS akut. ${ }^{8,12,27}$ Pada SH, suatu studi prospektif multisenter pertama dilakukan oleh Foerch dkk yang dinamakan "biomarker for rapid diagnosis of hemispheric stroke" (BE FAST trial). Pada studi ini terdapat hubungan antara volume PIS dengan kadar GFAP serum, dimana kadar GFAP $>1,91 \mathrm{ng} / \mathrm{mL}$ ditemukan pada keadaan PIS akut dengan rentang antara $0,02-236,27 \mathrm{ng} / \mathrm{mL} .{ }^{27}$

Penelitian oleh Xiong dkk melakukan pengambilan sampel dalam waktu 2-6 jam onset gejala stroke, dan serum level GFAP ditentukan melalui metode ELISA. Luaran klinis fungsional dari pasien ditentukan dengan mRS 90 hari setelah onset. Penelitian ini melibatkan 43 pasien SH. Korelasi signifikan ditemukan ketika membandingkan kadar GFAP dengan skor NIHSS $(r=0,418 ; \mathrm{p}<0,005)$ serta volume perdarahan $(\mathrm{r}=0,840 ; \mathrm{p}<0,001)$ pada kelompok SH. ${ }^{9}$

Penelitian ini memiliki keterbatasan antara lain pengambilan sampel untuk pemeriksaan kadar GFAP melalui darah vena, bukan dari sampel cairan serebrospinal (CSS). Penelitian ini mengambil subjek dengan ICH score $<3$ sehingga mungkin kurang mewakili kadar GFAP serum pada pasien SH yang semestinya akan lebih tinggi kadarnya pada pasien dengan klinis yang lebih buruk saat awal onset. Penelitian ini tidak memasukkan variabel infeksi ataupun komplikasi lain sebagai salah satu perancu yang dapat berpengaruh terhadap luaran klinis neurologis pasien SH. Selain itu, masih banyak biomarker potensial yang berkaitan dengan cedera otak neuronal paska SH yang belum diukur pada penelitian ini.

\section{KESIMPULAN}

Terdapat hubungan bermakna antara kadar GFAP serum yang diambil $\leq 72$ jam onset $\mathrm{SH}$ dengan 
perubahan NIHSS yang diukur pada hari ketiga dan ketujuh serta mRS 30 hari setelah onset pasien SH. Kadar GFAP serum yang semakin besar menunjukkan luaran klinis yang jelek pada pasien SH.

\section{DAFTAR PUSTAKA}

1. Sacco RL, Kasner SE, Broderick JP, Caplan LR, Connors JJ, Culebras A, dkk. An updated definition of stroke for the 21st century: A statement for healthcare professionals from the American Heart Association/American Stroke Association. Stroke. 2013;44(7):2064-89.

2. Caplan LR, Kase CS. Stroke a clinical approach. Edisi ke-5. Cambridge: Cambridge University Press; 2016. h. 477-510.

3. Boccardi E, Cenzato M, Curto F, Longoni M, Motto C, Oppo V, dkk. Hemorrhagic stroke. Milano: Springer; 2017. h. 2-27.

4. Steiner T, Al-Shahi Salman R, Beer R, Christensen $\mathrm{H}$, Cordonnier C, Csiba L, dkk. European Stroke Organisation (ESO) guidelines for the management of spontaneous intracerebral hemorrhage. Int $\mathrm{J}$ Stroke. 2014;9(7):840-55.

5. Chen S, Yang Q, Chen G, Zhang JH. An update on inflammation in the acute phase of intracerebral hemorrhage. Translational stroke research. 2015;6(1):4-8.

6. Volbers B, Willfarth W, Kuramatsu JB, Struffert T, Dorfler A, Huttner HB, Schwab S, Staykov D. Impact of perihemorrhagic edema on short-term outcome after intracerebral hemorrhage. Neurocritical care. 2016;24(3):404-12.

7. Ren C, Kobeissy F, Alawieh A, Li N, Li N, Zibara $\mathrm{K}$, dkk. Assessment of serum UCH-L1 and GFAP in acute stroke patients. Sci Rep. 2016;6(1):1-9.

8. Luger S, Witsch J, Dietz A, Hamann GF, Minnerup J, Schneider H, dkk. Glial fibrillary acidic protein serum levels distinguish between intracerebral hemorrhage and cerebral ischemia in the early phase of stroke. Clin Chem. 2017;63(1):377-85.

9. Xiong L, Yang Y, Zhang M, Xu W. The use of serum glial fibrillary acidic protein test as a promising tool for intracerebral hemorrhage diagnosis in Chinese patients and prediction of the short-term functional outcomes. Neurol Sci. 2015;36(11):2081-7.

10. Hol EM, Pekny M. Glial fibrillary acidic protein (GFAP) and the astrocyte intermediate filament system in diseases of the central nervous system. Current opinion in cell biology. 2015;32:121-30.

11. Liu G, Geng J. Glial fibrillary acidic protein as a prognostic marker of acute ischemic stroke. Hum Exp Toxicol. 2018;37(10):1048-53.
12. Perry LA, Lucarelli T, Penny-Dimri JC, McInnes MD, Mondello S, Bustamante A, dkk. Glial fibrillary acidic protein for the early diagnosis of intracerebral hemorrhage: Systematic review and meta-analysis of diagnostic test accuracy. Int J Stroke. 2018:2018:110.

13. Rozanski M, Waldschmidt C, Kunz A, Grittner U, Ebinger M, Wendt M, dkk. Glial fibrillary acidic protein for prehospital diagnosis of intracerebral hemorrhage. Cerebrovasc Dis. 2017;43(1-2):76-81.

14. Dvorak F, Haberer I, Sitzer M, Foerch C. Characterisation of the diagnostic window of serum glial fibrillary acidic protein for the differentiation of intracerebral haemorrhage and ischaemic stroke. Cerebrovasc Dis. 2009;27(1):37-41.

15. Petzold A. Glial fibrillary acidic protein is a body fluid biomarker for glial pathology in human disease. Brain Res. 2015;1600:17-31.

16. Kerr DM, Fulton RL, Lees KR. Seven-day NIHSS is a sensitive outcome measure for exploratory clinical trials in acute stroke: Evidence from the virtual international stroke trials archive. Stroke. 2012;43(5):1401-3.

17. Huybrechts KF, Jaime Caro J. The Barthel Index and modified Rankin Scale as prognostic tools for longterm outcomes after stroke: A qualitative review of the literature. Curr Med Res Opin. 2007;23(7):162736.

18. Sarder AH, Das BK, Mondal KJ, Kabir MA, Basu B, Alam MM. 30-days outcome of haemorrhagic stroke: Correlation between intracerebral hemorrhage score and modified Rankin Score. 2018;5(1):10-4.

19. Xing Y, An Z, Zhang X, Yu N, Zhao W, Ning X, dkk. Sex differences in the clinical features, risk factors, and outcomes of intracerebral hemorrhage: A large hospital-based stroke registry in China. Sci Rep. 2017;7(1):1-9.

20. Willers C, Lekander I, Ekstrand E, Lilja M, PessahRasmussen H, Sunnerhagen KS, dkk. Sex as predictor for achieved health outcomes and received care in ischemic stroke and intracerebral hemorrhage: A register-based study. Biol Sex Differ. 2018;9(1):1-9.

21. Hsieh JT, Ang BT, Ng YP, Allen JC, King NKK Comparison of gender differences in intracerebral hemorrhage in a multi-ethnic Asian population. PLoS One. 2016;11(4):1-10.

22. Lopresti MA, Bruce SS, Camacho E, Kunchala S, Dubois BG, Bruce E, dkk. Hematoma volume as the major determinant of outcomes after intracerebral hemorrhage. J Neurol Sci. 2014;345(1-2):3-7.

23. Hemphill JC, Greenberg SM, Anderson CS, Becker $\mathrm{K}$, Bendok BR, Cushman M, dkk. Guidelines for the management of spontaneous intracerebral 
hemorrhage: A guideline for healthcare professionals from the American Heart Association/American Stroke Association. Stroke. 2015;46(7):2032-60.

24. Lattanzi S, Silvestrini M. Blood pressure in acute intra-cerebral hemorrhage. Ann Transl Med. 2016;4(16).

25. Yang Z, Wang KKW. Glial fibrillary acidic protein: From intermediate filament assembly and gliosis to neurobiomarker. Trends Neurosci. 2015;38(6):36474.
26. Mayer CA, Brunkhorst R, Niessner M, Pfeilschifter W, Steinmetz H, Foerch C. Blood levels of glial fibrillary acidic protein (GFAP) in patients with neurological diseases. PLoS One. 2013;8(4):1-5.

27. Katsanos AH, Makris K, Stefani D, Koniari K, Gialouri E, Lelekis M, Chondrogianni M, Zompola C, Dardiotis E, Rizos I, Parissis J. Plasma glial fibrillary acidic protein in the differential diagnosis of intracerebral hemorrhage. Stroke. 2017;48(9):25868. 